discriminated against on grounds of their sexual orientation contrary to regulation 3 of the Regulations, which he held were not inconsistent with the ECHR. The judge gave permission to appeal. [RA]

doi:10.1017/So956618X11000573

\title{
Re St George, Tombland
}

Norwich Consistory Court: Arlow Dep Ch, January 2011

Public notice - advertising consent

A faculty was granted for the installation of heritage interpretation panels on the perimeter wall of the church. In re-opening the petition, the deputy chancellor upheld the objections of local residents challenging the display of the external public notice in the church porch, which was, at times at least, behind locked grille gates, stating that the notice had not been 'readily visible to the public' pursuant to rule 6 of the Faculty Jurisdiction Rules 2000. Repetition of the public notice period was directed. The deputy chancellor stated that the grant of advertising consent did not carry the same weight in faculty applications as did the grant of planning permission, given the lack of a public consultation process for the former. [RA]

\section{Re St Andrew, Alwalton \\ Ely Consistory Court: Jones Dep Ch, January 2011 \\ Exhumation - churchyard regulations - reinterment - ECHR}

The petitioner and her family objected to the enforcement by the incumbent and PCC of the chancellor's churchyard regulations in so far as that involved the removal of items, such as vases, that had been placed on the plot containing the cremated remains of the petitioner's late husband. The petitioner accordingly sought a faculty for the exhumation of the cremated remains on the basis that she would then retain them at her own home until she herself died. The deputy chancellor held that the petitioner's objection to the enforcement of the churchyard regulations did not amount to a special reason for departing from the norm that Christian burial was permanent. Even if, as the deputy chancellor was prepared to assume, the petitioner had been mistaken as to precisely what might be permitted in terms of the placing of flowers and containers in the churchyard, the churchyard regulations did not completely prohibit the placing 
of such items. The fact that what was permitted did not accord in all respects with what the petitioner and her family might have wished did not amount to a 'mistake' of the sort that would justify an exception from the presumption against exhumation. To grant a petition based on an objection to the enforcement of the churchyard regulations would not only undermine the principle of the permanence of burial but would also risk undermining the role of those responsible for enforcing the regulations. The deputy chancellor declined to grant a faculty. He went on to hold that, even if a case for exhumation had been made out, he would have been loath to grant a faculty permitting the exhumation of the remains when it was clear that the petitioner had no intention of arranging for them to be immediately re-interred elsewhere. The deputy chancellor went on to consider the application of various articles of the European Convention on Human Rights and associated case law and held that the relevant ecclesiastical law was consistent with the applicable articles of the Convention. [Alexander McGregor]

\section{Re Streatham Park Cemetery}

Southwark Consistory Court: Petchey Ch, February 2011

Exhumation - exceptional circumstances - circumstances of original interment

The petitioner's father had been buried in the consecrated part of Streatham Park Cemetery in 1961 in the same grave as a stillborn child of his parents. The petitioner's mother had been buried in the Roman Catholic part of the same cemetery in 1958. The petitioner sought a faculty to exhume the remains of his father in order that they should be reinterred in a cemetery in Belgium together with the remains of his mother, whose remains it was also proposed to exhume. The petition was advanced on the ground that the petitioner's father had wanted to be buried with the petitioner's mother and that his burial in the grave of the stillborn child of his parents had not been in accordance with his wishes. The proposal that re-interment should be in Belgium arose because the petitioner's parents had met there during the Second World War and there remained numerous family members in Belgium. The petitioner was not content that his parents should be re-interred together in Streatham Park Cemetery because of concerns he had about standards of maintenance there. The Roman Catholic authorities supported what was proposed, so far as they related to the exhumation of the petitioner's mother. The chancellor concluded that, after such a lapse of time, it was difficult to conclude on slender evidence 